\title{
Cytoadherence phenotype of Plasmodium falciparum-infected erythrocytes is associated with specific pfemp-1 expression in parasites from children with cerebral malaria
}

Talleh Almelli' ${ }^{1,2}$, Nicaise T Ndam ${ }^{1,2}$, Sem Ezimegnon ${ }^{3}$, Maroufou J Alao ${ }^{4}$, Charles Ahouansou ${ }^{3}$, Gratien Sagbo $^{5}$, Annick Amoussou ${ }^{6}$, Philippe Deloron ${ }^{1,2}$ and Rachida Tahar ${ }^{1,2^{*}}$

\begin{abstract}
Background: Cytoadherence of Plasmodium falciparum-infected erythrocytes (IEs) in deep microvasculature endothelia plays a major role in the pathogenesis of cerebral malaria (CM). This biological process is thought to be mediated by $P$. falciparum erythrocyte membrane protein-1 (PfEMP-1) and human receptors such as CD36 and ICAM-1. The relationship between the expression of PfEMP-1 variants and cytoadherence phenotype in the pathology of malaria is not well established.
\end{abstract}

Methods: Cytoadherence phenotypes of IEs to CD36, ICAM-1, CSPG and the transcription patterns of A, B, var2csa, var3, var gene groups and domain cassettes DC8 and DC13 were assessed in parasites from children with CM and uncomplicated malaria (UM) to determine if cytoadherence is related to a specific transcription profile of pfemp-1 variants.

Results: Parasites from CM patients bind significantly more to CD36 than those from UM patients, but no difference was observed in their binding ability to ICAM-1 and CSPG. CM isolates highly transcribed groups A, B, var2csa, var3, DC8 and DC13 compared to UM parasites. The high transcription levels of var genes belonging to group B positively correlated with increased binding level to CD36.

Conclusion: $\mathrm{CM}$ isolates bind significantly more to CD36 than to ICAM-1, which was correlated with high transcription level of group B var genes, supporting their implication in malaria pathogenesis.

Keywords: Plasmodium falciparum, Cerebral malaria, Uncomplicated malaria, Var genes, Domain cassette, Transcript abundance, Cytoadherence, CD36, ICAM-1, CSPG, CSA

\section{Background}

Cerebral malaria $(\mathrm{CM})$ is one of the serious manifestations of falciparum malaria. Despite an adequate treatment, $15-20 \%$ of infants presenting with CM die in hospital [1]. There is strong evidence that sequestration of Plasmodium falciparum-infected erythrocytes (IEs) within the brain microvascular endothelia plays a key

\footnotetext{
* Correspondence: Rachida.Tahar@ird.fr

1 Institut de Recherche pour le Développement (IRD), UMR 216 Mère et Enfant Face aux Infections Tropicales, 4, avenue de l'Observatoire, Paris 75270, France

${ }^{2}$ PRES Sorbonne Paris Cité, Université Paris Descartes, Faculté de Pharmacie, Paris, France

Full list of author information is available at the end of the article
}

role in $\mathrm{CM}$ pathogenesis [2,3]. This and comparable in $\mathrm{CM}$ and $\mathrm{UM}$ isolates. Howeverphenomenon protects the mature parasites from spleen-dependent clearance [4]. The adhesive properties of IEs are attributed to $P$. falciparum Erythrocyte Membrane Protein-1 (PfEMP-1) expressed at the surface of IEs [5]. Encoded by 60 members of var gene family, pfemp-1 genes are divided into three main groups (A, B and C) and three relatively conserved groups var1, var2csa and var3 [6]. It has been shown that groups A and B var genes are differentially transcribed in isolates associated with severe malaria, compared with parasites from uncomplicated malaria (UM) or asymptomatic infections [7-9]. Recent

\section{Ciomed Central}

(c) 2014 Almelli et al.; licensee BioMed Central Ltd. This is an Open Access article distributed under the terms of the Creative Commons Attribution License (http://creativecommons.org/licenses/by/4.0), which permits unrestricted use, distribution, and reproduction in any medium, provided the original work is properly credited. The Creative Commons Public Domain Dedication waiver (http://creativecommons.org/publicdomain/zero/1.0/) applies to the data made available in this article, unless otherwise stated. 
studies have shown that PfEMP-1 s are characterized by 23 conserved architectural motifs named domain cassettes (DC) and that DC8 and DC13 are of clinical significance. The transcription levels of these DCs are higher in parasites from severe malaria, including CM, than in those from UM $[10,11]$. Moreover, $P$. falciparum parasites selected for binding to human brain microvascular endothelial cells (HBMEC) express high levels PfEMP-1 DC8 genes [12], and plasma from convalescent patients exhibited higher antibody recognition profiles to HBMEC-selected parasites than unselected ones, suggesting the importance of PfEMP-1 motifs in building protective immunity to malaria $[12,13]$.

In vitro experiments identified a few endothelial receptors that participate in the adherence of IEs to microvasculature endothelia. CD36 and Inter Cellular Adhesion Molecule-1 (ICAM-1) are the most commonly used receptors by clinical isolates [14]. As yet, apart from chondroitin sulphate A proteoglycan (CSPG), which is the main receptor of parasites isolated from pregnant women, no definite candidate has been determined for cerebral malaria pathology [15]. It has been shown that parasites infecting children or non-pregnant host have very low binding to CSA, suggesting a role of other receptors in the pathology of malaria in non pregnant women $[16,17]$. CD36 is considered as a common receptor involved in the cytoadherence of $P$. falciparum isolates [18-20]. Several studies have found no difference in CD36-binding patterns between parasites from severe malaria and those from UM patients $[17,21]$, while others have reported an association between UM and high binding level to CD36 [22,23]. Post-mortem brain examination has reported high levels of ICAM-1, which co-localized with IEs in cerebral blood vessels [24]. This finding is in agreement with studies that suggested an association between disease severity and ICAM-1-binding [23]. However, some studies did not detect any difference in binding to ICAM-1 in parasite isolates from severe or mild cases $[20,25]$.

The involvement of CD36 and ICAM-1 as well as that of PfEMP-1 variant expression in the pathogenesis of $\mathrm{CM}$ has not been well established. Recently, Turner et al identified the Endothelial Protein C Receptor (EPCR) as a new mediator of IEs adhesion to microvascular endothelial cells via the interaction with domain cassette 8 and 13 of PfEMP-1 variants.

To investigate the relationship between PfEMP-1 variant expression and cytoadhesion to CD36, ICAM-1 and CSPG the binding phenotype as well as the transcript abundance of pfemp-1 variants of parasites freshly collected from Beninese children with $\mathrm{CM}$ or UM was carried out by static binding assay and rtqPCR respectively. The binding assay to EPCR was not investigated in this study.

\section{Methods}

Ethics statement

This study was reviewed and approved by the ethics committee of the Research Institute of Applied Biomedical Sciences, Cotonou, Benin (No 006/CER/ISBA/12 and No 21/CER/ISBA/13).

\section{Study design, malaria patients}

This study was conducted in Cotonou, southern Benin, during the 2012 and 2013 malaria transmission periods (June-September and May-July, respectively). This area is characterized by two rainy seasons during which malaria infection is mainly caused by $P$. falciparum, with approximately 33 infective bites per person annually [26].

Children under five years of age spontaneously presenting at Hôpital Mère-enfant de la Lagune (HOMEL), Centre National Hospitalier Universitaire Hubert Koutoucou Mega (CNHU-HKM), or to Hôpital Suru-Léré were screened by rapid diagnostic test for malaria (DiaQuick Malaria P. falciparum Cassette, Dialab ${ }^{\oplus}$; Hondastrasse, Austria) and were recruited in the study if they presented CM or UM. CM was defined as a microscopically confirmed $P$. falciparum infection and a Blantyre coma score $\leq 2$, with the exclusion of any other causes of coma. UM was defined as P. falciparum parasitaemia accompanied by fever, headache, or myalgia without signs of severity and/or evidence of vital organ dysfunction, as defined by the World Health Organization (WHO) [27]. After obtaining informed and written consent from parents or guardians, 2 to $4 \mathrm{ml}$ of venous blood samples were collected into tubes containing citrate phosphate dextrose adenine. Plasmodium falciparum infections were confirmed by microscopic examination of Giemsa-stained thick blood smears, and parasitaemia was recorded as the number of asexual parasites $/ \mu \mathrm{L}$ of blood. All participants were treated according to the guidelines established by the Beninese Ministry of Health.

\section{Sample preparation and parasite culture}

Plasma and buffy coat were removed from fresh parasitized blood samples, and red cell pellet was washed twice in RPMI 1640 medium (LONZA, Amboise, France) containing $50 \mathrm{mg} / \mathrm{ml}$ gentamicin by centrifugation $(800 \mathrm{~g} \times$ $10 \mathrm{~min})$. One-hundred $\mu \mathrm{l}$ were conserved in TRIzol $^{\oplus}$ reagent (Life Technologies, Illkirch, France), and stored at $-80^{\circ} \mathrm{C}$ for RNA extraction. Another $100 \mu \mathrm{l}$ were spotted on Whatman 3MM filter paper, and stored at room temperature for DNA extraction and merozoite surface protein-1 ( $m s p-1)$ and $m s p-2$ genotyping. Five-hundred $\mu$ l were cultured in RPMI 1640 medium supplemented with $10 \%$ human serum. Parasites were cultured for less than 48 hours until they reached the mature stage (mature trophozoites and schizonts) and purified using 
magnetic columns (MACS, Milteny Biotec, Bergisch Gladbach, Germany) for binding assay.

\section{Binding assay}

Static binding assays were performed with $27 \mathrm{UM}$ and $38 \mathrm{CM}$ fresh isolates at $20 \%$ parasitaemia in $100 \times 15$ $\mathrm{mm}$ Petri dishes as described [28]. Twenty $\mu \mathrm{l}$ of each recombinant protein diluted in phosphate buffer saline (PBS) were spotted on Petri dish and incubated overnight at $4^{\circ} \mathrm{C}$ in a sealed humid container. The following recombinant proteins were used: CSPG at $5 \mu \mathrm{g} / \mathrm{ml}$ (Decorin, Sigma-Aldrich, Saint-Quentin Fallavier, France), CD36 and ICAM-I at $10 \mu \mathrm{g} / \mathrm{ml}$ (R\&D, Lille, France). The spots were blocked with $3 \%$ bovine serum albumin (BSA) in PBS for $30 \mathrm{~min}$ at $37^{\circ} \mathrm{C}$ in a humid chamber. Purified parasites were washed with PBS, centrifuged for $10 \mathrm{~min}$ at $800 \mathrm{~g}$, resuspended in 3\% BSA in RPMI 1640 medium and $20 \mu \mathrm{l}$ of parasite suspension were added to each spot and incubated for $12 \mathrm{~min}$ at room temperature. Unbound erythrocytes were washed off gently with PBS using an automated washing system. Bound cells were fixed with $1.5 \%$ glutaraldehyde in PBS for $10 \mathrm{~min}$, Giemsa-stained and counted microscopically. The number of IEs bound to each receptor was determined by counting ten fields using a $40 \times$ objective, and expressed as the number of IEs bound per sq $\mathrm{mm}$. For each sample, the binding assay was done in duplicate for all proteins in the same plate. Results were expressed as the mean binding level of duplicate spots per sample. As a negative control, 1\% BSA was used to assess non-specific binding. This protocol has been standardized using FCR3-CSA and FCR3-CD36 binding parasite strains.

As documented in several studies CSA binding phenotype is highly correlated with the expression of VAR2CSA in IEs from pregnant women [29-31]. Therefore, CSA binding experiment and var2csa transcript abundance assessment as a second negative control were included. The binding to CSA and transcription of var2csa in parasite from children are expected to be low or undetectable.

\section{Parasite RNA extraction and CDNA synthesis}

cDNAs were synthesized from $36 \mathrm{UM}$ and $51 \mathrm{CM}$ samples preserved in TRIzol ${ }^{\circ}$ reagent, following the manufacturer's instructions. RNAs were treated with DNAse I (BioLabs, Ipswich, MA), and the absence of genomic DNA was assessed by 40 cycles of RT-PCR with fructose-biphosphate aldolase primers [29]. Reverse transcription of RNA was performed by Thermoscript ${ }^{\circ}$ (Life Technologies) with random hexamers and oligo dt primers, following manufacturer's recommendations.

\section{Transcript abundance level of var genes}

Individual RT-PCR reactions were performed using Rotorgene $^{ø}$ thermal cycler (Corbett Research) with 1X SYBR
Green $^{\circ}$ (Bioline) and $1.25 \mu \mathrm{M}$ of specific primer pairs for group A (A1, A2, A3), group B (B1), var2csa and var3 of var genes. A set of primers that target $\mathrm{DC} 8$ and $\mathrm{DC} 13$ was also used [10]. The endogenous controls used were fructose-bisphosphate aldolase and seryl-tRNA synthetase [29]. Cycling conditions were $95^{\circ} \mathrm{C}$ for $1 \mathrm{~min}$, followed by $40 \mathrm{cy}-$ cles of $95^{\circ} \mathrm{C}$ for $30 \mathrm{sec}, 54^{\circ} \mathrm{C}$ for $40 \mathrm{sec}$, and $68^{\circ} \mathrm{C}$ for $50 \mathrm{sec}$. Data were analysed by the Rotorgene software for which the threshold cycle was set at 0.025 . The specificity of each PCR product was verified by the specific melting curve for each pair of primers. The transcript abundance was calculated by relative quantification using two housekeeping genes $\left(\Delta \mathrm{Ct}{ }_{\text {var_primer }}=\mathrm{Ct} \mathrm{vr}_{\text {r_primer }}-\mathrm{Ct} \mathrm{tavage}_{\text {anantrol primers }}\right)$. Transcript units were determined as $\mathrm{Tu}=2^{(5-\bar{\Delta} \mathrm{Ct})}[10]$.

\section{Genomic DNA extraction and $m s p 1$ and $m s p 2$ genotyping}

Genomic DNA was extracted from filter papers using the Chelex 100 resin method [32]. Specific primers were used to amplify block 2 of $m s p-1$ and block 3 of $m s p-2$ [33]. Multiplicity of infection (MOI) was defined as the highest $m s p-1$ or $m s p-2$ allele number found in each sample.

\section{Statistical analysis}

Binding data were expressed as the number of IEs $/ \mathrm{mm}^{2}$ bound to a given receptor minus the number of IEs bound to BSA. The non-parametric Mann-Whitney U test was used to compare the binding levels to receptors and the transcript abundance of var group genes and DC8 and DC13 between CM and UM groups. Correlation coefficient between binding profile and transcript level of dominant var group, which was transcribed in more than $50 \%$ of samples, was calculated by the Spearman's rank test. Data were plotted and statistical tests were performed using Prism v5 software (GraphPad Software, Inc., San Diego, CA, USA). The level of statistical significance was set at 0.05 .

\section{Results}

A total of 88 children were enrolled, including 52 children with CM and 36 with UM. Of 52 children with $\mathrm{CM}, 21$ presented CM alone, while the others had overlapping clinical syndromes: 25 with severe anaemia (SA), and 16 with hyperparasitaemia (HP) defined as parasite density $\geq 250.000 \mathrm{p} / \mu \mathrm{l}$ (ten children with $\mathrm{CM}$ presented both SA and HP). The clinical and biological features of these patients are summarized in Table 1 . There was no difference $(P>0.05)$ in the mean age, sex ratios and mean body temperature between the two groups. However, the mean haemoglobin level was lower $(\mathrm{P}<0.0001)$, while the mean parasite density was higher $(\mathrm{P}<0.01)$ in CM group than UM group. All children with UM survived, while 19 patients (36.5\%) with CM died. Multiple infections were recorded in both groups, with a mean 
Table 1 Parasitological and clinical characteristics of children enrolled in Cotonou, 2012-2013

\begin{tabular}{|c|c|c|c|}
\hline & $\begin{array}{l}\text { Cerebral } \\
\text { malaria } \\
(\mathrm{N}=52)\end{array}$ & $\begin{array}{l}\text { Uncomplicated } \\
\text { malaria }(\mathrm{N}=36)\end{array}$ & P-value \\
\hline Sex ratio (female/male) & $23 / 29$ & $18 / 18$ & 0.2 \\
\hline $\begin{array}{l}\text { Age (months), } \\
\text { median [range] }\end{array}$ & $42[5-72]$ & 33 [8-58] & 0.09 \\
\hline $\begin{array}{l}\text { Parasitaemia }(\mathrm{P} / \mu \mathrm{ll}), \\
\text { median [range] }\end{array}$ & $\begin{array}{l}75,806[889- \\
3,600,000]\end{array}$ & $\begin{array}{l}49,453.5 \\
{[1,164-246,857]}\end{array}$ & 0.01 \\
\hline $\begin{array}{l}\text { Haemoglobin }(\mathrm{g} / \mathrm{dl}) \text {, } \\
\text { median [range] }\end{array}$ & $5.15[0.8-12.6]$ & $7.45[5.2-12.5]$ & 0.0001 \\
\hline $\begin{array}{l}\text { Blantyre score, } \\
\text { median [range] }\end{array}$ & $2[0-2]$ & - & - \\
\hline $\begin{array}{l}\text { Temperature, } \\
\text { median [range] }\end{array}$ & $\begin{array}{l}38^{\circ} \mathrm{C}\left[35.5-40^{\circ}\right. \\
\mathrm{C}]\end{array}$ & $\begin{array}{l}38.5^{\circ} \mathrm{C} \\
{\left[36.5-40^{\circ} \mathrm{C}\right]}\end{array}$ & 0.15 \\
\hline $\begin{array}{l}\text { Multiplicity of infection, } \\
\text { median [range] }\end{array}$ & $3.4[1-6]$ & $2.2[1-6]$ & 0.0001 \\
\hline Number of deaths & 19 & 0 & - \\
\hline
\end{tabular}

MOI of 3.4 distinct parasite populations in $\mathrm{CM}$ and 2.2 parasite populations in UM group $(\mathrm{P}<0.0001)$, These MOI values are consistent with the high endemicity of malaria in the study site.

\section{Binding profiles}

Due to the low parasitaemia of some UM isolates (geometric mean parasite density, 23,078 asexual parasites/ $\mu \mathrm{l}$ range, $(75-246,857)$ asexual parasites/ $\mu \mathrm{l})$ and anti-malarial treatment before enrolment in some of the $\mathrm{CM}$ children, in vitro parasite cultivation was successful among 27 of 36 isolates in the UM group and 38 of 52 isolates in the CM group. The binding phenotypes were analysed in 65 isolates that developed into mature forms. All but two isolates (63 of 65) bound to both CD36 and ICAM-1, and 48 isolates bound weakly to CSPG (Table 2).

Cytoadherence levels were compared between CM and UM samples separately to each receptor. The binding of $\mathrm{CM}$ isolates to CD36 was significantly higher $(P=0.015)$ than that of UM samples. However, there was no significant difference in the binding level to ICAM-1 $(P=0.4)$ or to CSPG $(P=0.1)$ between CM and UM isolates Figure 1.

Table 2 Receptor binding data

\begin{tabular}{llll}
\hline & $\begin{array}{l}\text { Cerebral malaria } \\
(\mathbf{n}=\mathbf{3 8})\end{array}$ & $\begin{array}{l}\text { Uncomplicated malaria } \\
(\mathbf{n}=\mathbf{2 7})\end{array}$ & $\begin{array}{l}\text { All samples } \\
\mathbf{( n = 6 5 )}\end{array}$ \\
\hline CD36 & $350.5(0-2552)$ & $85.1(0-379)$ & $244.0(0-2552)$ \\
ICAM-1 & $48.3(0.6-215)$ & $39.3(0-294)$ & $45.2(0-294)$ \\
CSPG & $11.3(0-62)$ & $9.6(0-72)$ & $10.7(0-72)$ \\
\hline
\end{tabular}

Values are the mean number of infected erythrocytes bound (range)/ $/ \mathrm{mm}^{2}$ to a given receptor minus the number of infected erythrocytes bound to BSA.
Transcript levels of var gene groups, DC8, and DC13

The transcription level of A, B,var2csa, var3, DC8, and DC13 var genes was analysed by RT-qPCR in $36 \mathrm{UM}$ and $51 \mathrm{CM}$ isolates. Group A, B, var2csa, var3, DC8, and DC13 had significantly higher levels of transcription $(\mathrm{P}<0.05)$ in $\mathrm{CM}$ isolates than in UM isolates (Table 3, Figures 2 and 3). However, no difference in the transcription level was observed between CM and UM isolates when genes were targeted by A2, DBL $4 / 6$ and DBL $\alpha$ CIDR $\alpha$ primer sets.

\section{Correlation between binding phenotype and transcription level of var genes}

The relationship between binding profiles and transcription level of var gene groups and DCs for each isolate was examined by considering only highly transcribed genes that were determined as 'predominant transcripts'.

Group B var genes were the predominant transcripts in $51 \%$ of samples. Tu value of group B var genes was positively correlated with the binding level to CD36 $(\mathrm{r}=0.46, P=0.005)$, but not with binding to ICAM-1 $(\mathrm{r}=0.05, P=0.7)$ or CSPG $(\mathrm{r}=0.1, P=0.2)$. Group A var genes were the predominant transcripts in $49 \%$ of samples, and no significant correlation was observed between $\mathrm{Tu}$ values and binding levels to CD36 $(\mathrm{r}=0.2, P=0.2)$, ICAM$1(\mathrm{r}=0.1, P=0.4)$, or CSPG $(\mathrm{r}=-0.02, P=0.1)$.

Likewise, DC8 and DC13 genes were predominant in 78.5 and $21.5 \%$ of samples, respectively. Tu values of DC8 and DC13 were not correlated with binding the levels to $\mathrm{CD} 36(\mathrm{r}=-0.005,[\mathrm{P}=0.9]$ and $\mathrm{r}=0.09[\mathrm{P}=0.7]$, respectively), ICAM-1 $(r=0.1,[P=0.4]$ and $r=-0.06$, $[\mathrm{P}=0.8]$, respectively) and CSPG $(\mathrm{r}=0.05[\mathrm{P}=0.7]$ and $r=-0.1[P=0.5]$, respectively).

\section{Discussion}

Cytoadherence of IEs to cerebral microvasculature cell lining is considered to be the major factor in CM pathogenesis $[2,34]$. This mechanism is known to be mediated by PfEMP-1 variants expressed at the surface of IEs [35]. However, the exact ligand-receptor interactions leading to the binding of IEs to brain microvascular endothelium are not well understood.

To investigate the potential role of PfEMP-1 variants in cytoadherence to host receptor, clinical isolates from patients with cerebral or uncomplicated malaria were used to assess the cytoadherence phenotypes to ICAM-1, CD36, and CSPG and the transcription profiles of var genes.

The results suggest that CD36 is a common binding receptor used by clinical isolates from both UM and $\mathrm{CM}$, in agreement with earlier findings that showed the involvement of CD36 in cytoadherence $[14,18,19]$. However, contrary to the results of previous studies, CD36binding level was shown to be higher in isolates from $\mathrm{CM}$ group than those from UM group, suggesting the 


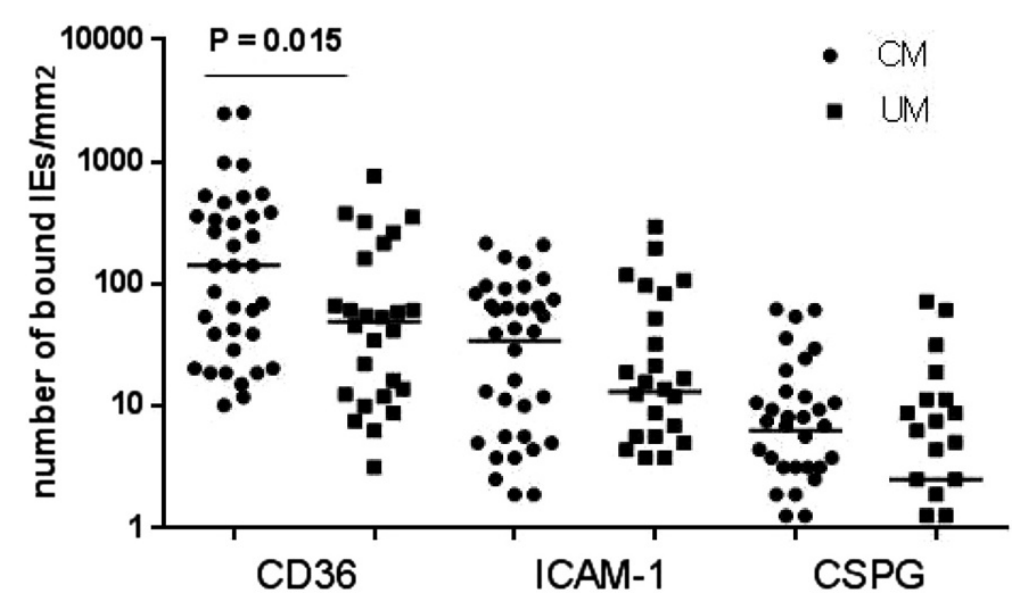

Figure 1 Binding level (number of bound IEs $/ \mathrm{mm}^{2}$ ) of CM and UM isolates on CSPG, ICAM-1 and CD36. The difference in binding levels to a specific receptor was tested by the Mann-Whitney $U$ test, significant $P$-value is shown in the figure.

key role played by CD36 in parasite sequestration during CM. This result oppose to the likely admitted assumption considering CD36 binding phenotype as common phenotype unrelated to parasite virulence.

Conversely, in agreement with previous studies using static binding assay [20,25], the binding level to ICAM-1 was low and comparable in $\mathrm{CM}$ and $\mathrm{UM}$ isolates. However, a higher binding level to ICAM-1 in CM isolates, as compared to that of UM isolates, was seen under flow conditions, as probably flow assay better

Table 3 Transcript abundances of var genes from groups A, B, var2csa, var3, DC8 and DC13

\begin{tabular}{|c|c|c|c|}
\hline Primers ID & $\begin{array}{l}\mathrm{T}_{\mathrm{u}} \text { CCM median } \\
{[\mathrm{IQR}]}\end{array}$ & $\begin{array}{l}\mathrm{T}_{\mathrm{u}}, \mathrm{UM} \text { median } \\
{[\mathrm{IQR}]}\end{array}$ & $P$-value \\
\hline$A 1(n=x x)$ & $1.4[1-6.8]$ & 1 [0-1.7] & 0.01 \\
\hline$A 2(n=x x)$ & $1.2[1-5.3]$ & 1 [1-6.3] & 0.8 \\
\hline A3 $(n=x x)$ & $19.6[4.3-33]$ & 6.6 [1-14.3] & 0.02 \\
\hline B1 $(n=x x)$ & 9.3 [1-64] & 1 [1-2.6] & 0.001 \\
\hline $\operatorname{var} 2(n=x x)$ & $1[1-4.4]$ & $1[0-1]$ & 0.001 \\
\hline $\operatorname{var3}(n=x x)$ & $17.1[1-34]$ & $1.4[1-10.4]$ & 0.008 \\
\hline $\begin{array}{l}\text { CIDRa1.1 (DC8) } \\
(n=x x)\end{array}$ & $2.11[1-11.8]$ & 1 [1-2.3] & 0.02 \\
\hline $\begin{array}{l}\text { DBL } \beta 12 \text { (DC8) } \\
(n=x x)\end{array}$ & 2.8 [1-13.9] & 1 [1-4.2] & 0.03 \\
\hline $\begin{array}{l}\text { DBLy4/6 (DC8) } \\
(n=x x)\end{array}$ & $1[0-1]$ & $1[0-1]$ & 0.4 \\
\hline $\begin{array}{l}\text { DBLaCIDRa (DC8) } \\
(\mathrm{n}=\mathrm{xx})\end{array}$ & 0 [0-1] & $0[0-1]$ & 0.4 \\
\hline $\begin{array}{l}\text { DBLa1.7 (DC13) } \\
(n=x x)\end{array}$ & $1.1[1-8.1]$ & 1 [ 0-1.5] & 0.01 \\
\hline $\begin{array}{l}\text { CIDRa1.4 (DC13) } \\
(\mathrm{n}=\mathrm{xx})\end{array}$ & 1 [1-2.2] & 1 [ 0-1] & 0.002 \\
\hline
\end{tabular}

Comparisons between $P$. falciparum isolates from children presenting with cerebral (CM) and uncomplicated malaria (UM) were achieved by the MannWhitney $U$ test. simulates physiological wall shear stress under which ICAM-1 promotes IEs rolling and binding [23]. Hence, the lower level of parasite binding to ICAM-1, as compared to CD36, observed in this study may also occur due to suboptimal interaction between ICAM-1 and IEs resulting from conformational changes of this receptor when immobilized on a plastic surface. Moreover, the significantly higher MOI in CM parasites may also endow $\mathrm{CM}$ group with higher number of parasites with CD36 binding phenotype.

The development of new binding assays closely mimicking physiological ligand-receptor interaction will provide relevant knowledge on receptor affinity to IEs. Moreover, it has been shown that P. falciparum isolates, including those from $\mathrm{CM}$, bind to CD36 ten-fold higher than to ICAM-1, and that $80 \%$ of ICAM-1-selected IEs bind to CD36, suggesting an association of CD36 with disease pathogenesis as it facilitates the binding of a high proportion of parasites to the endothelium in various deep organs [36]. In addition, under flow conditions, CD36 offers greater and more efficient adherence property than ICAM-1 [37]. These results are in agreement with data of this study showing a higher binding level of IEs to CD36 than ICAM-1.

Despite the fact that CD36 is poorly expressed in brain vascular endothelia, Turner et al. reported low but significant association between CD36 expression and IEs sequestration in brain vessels [38]. Moreover, IEs binding to cerebral endothelial cells may take place indirectly through platelets accumulated in the brain vasculature of CM patients [39]. Platelets express a high level of CD36, which may promote IEs binding and sequestration in the brain, despite the low CD36 expression on brain microvascular endothelium. Platelets were found to act as a bridge between CD36-deficient brain endothelium and IEs via CD36 binding. This mechanism 


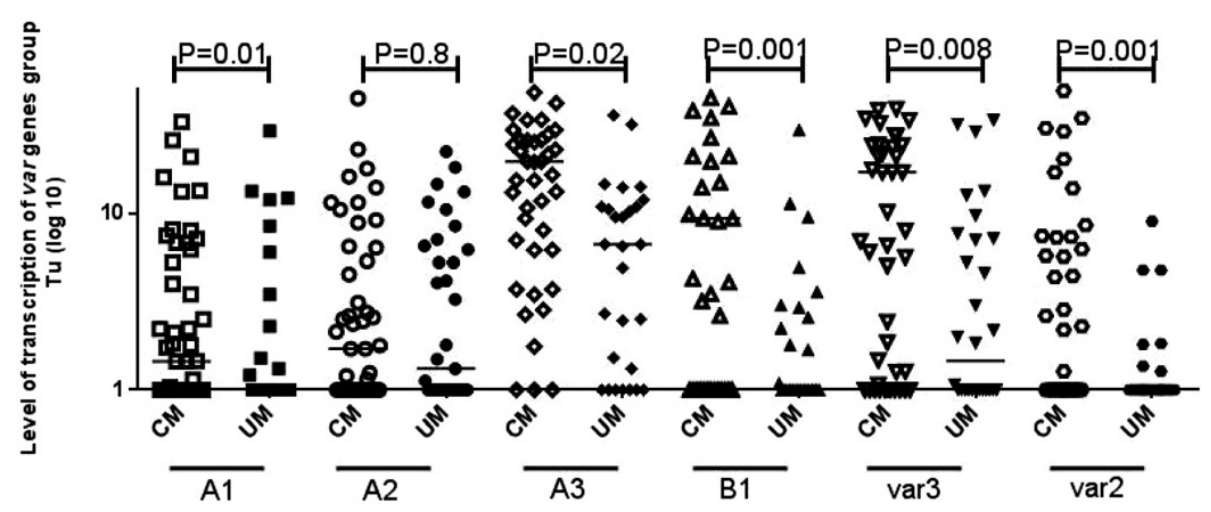

Figure 2 Transcript abundances of var genes from group A, B, var2csa and var3 in Plasmodium falciparum isolates from children presenting with either cerebral (CM) or uncomplicated malaria (UM). Transcript patterns of specific var genes were compared between groups by the Mann-Whitney $U$ test, significant $P$-values are shown in the figure.

possibly bestows IEs with more diversified binding properties, promoting CM pathogenesis [40].

PfEMP-1 variants expressed on the surface of IEs determine the cytoadherence properties of parasite populations [35]. These proteins are well-described ligands, and studies have shown that they recognize and interact with more than one receptor independently of IEs subpopulations. One PfEMP-1 variant may allow the cytoadherence to more than one host receptor through its semi-conserved N-terminal head structure DBL1 $\alpha$ and CIDR1 $\alpha$ [41]. Likewise, DBL $\beta 2$ and DBL 33 bind ICAM-1 [42-44]. The tandem NTS-DBL $\alpha-C I D R \gamma$ of varO is essential for IEs binding and rosette formation [45]. CIDR $\alpha 1$ of DC8 and DC13 var genes is a potential ligand of endothelial protein C receptor [44]. Moreover, multiple extracellular domains of DC8 of IT4var19 bound brain and non brain endothelial cells [46].

In this study, the transcription of $p f e m p-1$ variants including groups A, B, var3, DC8, and DC13 was clearly up-regulated in CM parasites as compared to UM isolates, in agreement with previous studies [8-11], supporting the implication of these genes in $\mathrm{CM}$ pathogenesis. var2csa is transcribed to a much higher level in isolates from pregnant than from non-pregnant women [30]. Some CM isolates expressed var2csa at a higher level than in UM parasites. However, binding to CSPG was consistently very weak and similar in both UM and CM groups, indicating that VAR2CSA does not take part in malaria pathogenesis in children. Although VAR2CSA expression was absent at the surface of IEs in isolates

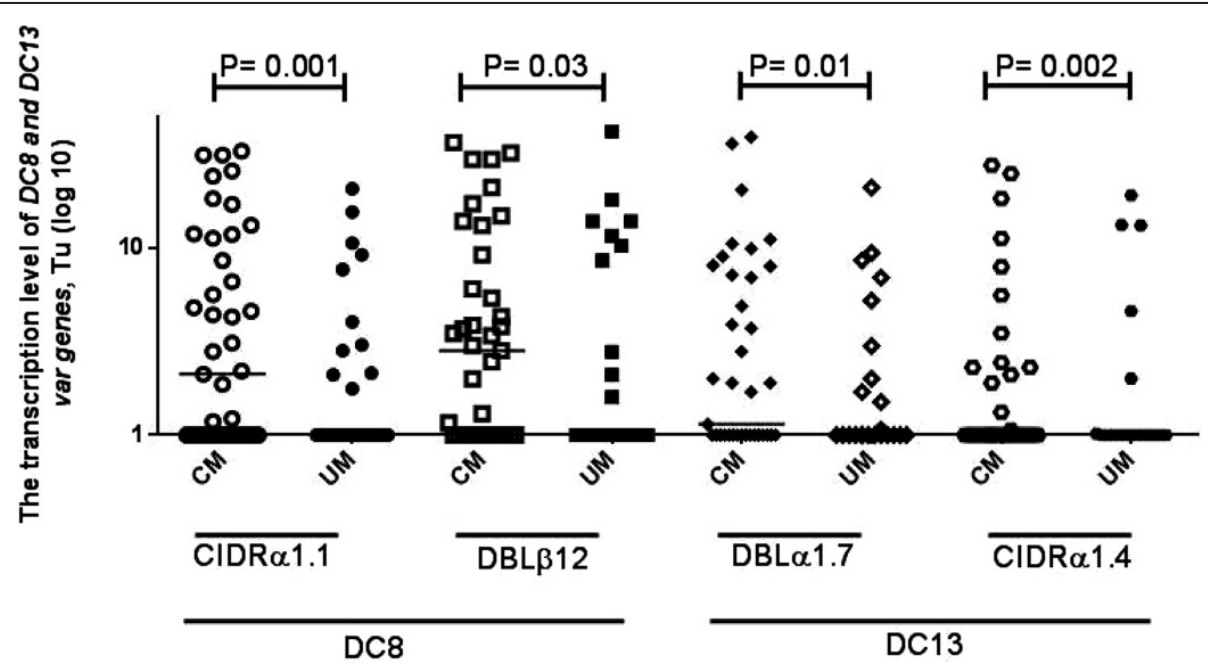

Figure 3 Transcript abundances of DC8 and DC13 targeted by CIDRa1.1, DBL $\beta 12$, DBLa1.7, and CIDRa1.4 primers in Plasmodium falciparum isolates from children presenting with either cerebral (CM) or uncomplicated malaria (UM). Transcript patterns were compared between groups by the Mann-Whitney $U$ test, significant $P$-values are shown in the figure. 
from children in other studies, its transcription was reported to be high in these isolates $[8,47]$.

The transcription level of group $B$ genes positively correlated with the binding level of IEs to CD36, confirming the earlier findings that parasite ligands for CD36 are PfEMP-1 variants encoded by var genes belonging to groups $B$ and $C$ through their CIDR1 $\alpha$ domain $[48,49]$. Functional analysis using mutagenesis in the M2 region of CIDR1 $\alpha$ linked CD36 binding ability to specific CIDR1 $\alpha$ residues [50]. Recombinant protein of CIDR $\alpha 1.1$ of DC8 also inhibits the binding of IEs to brain endothelium cells, suggesting a role of this domain in binding phenotypes involved in cerebral malaria. However, in this study, parasite lines that express IT4var6 and IT4var19 genes containing DC8 at high level and IT4var13 at low level were shown to bind weakly to CD36 [13]. Other studies using parasite lines selected to express only one pfemp-1 variant are needed to demonstrate specific PFEMP-1/host receptor combinations.

The transcription levels of DC8 and DC13 were higher in $\mathrm{CM}$ isolates as compared to those in UM isolates, but were not correlated with the binding levels to CD36, ICAM-1, or CSPG. DC8 and DC13 are part of few genes from groups $\mathrm{B}$ and $\mathrm{A}$, respectively. These two domain cassettes have been shown to mediate the binding of IEs to EPCR [51]. Positive correlation between DC8 and 13 expression and elevated binding to EPCR could be expected in CM parasites. It is possible that the present study did not include sufficient number of isolates expressing DC8 and DC13 and, for this reason, may have lacked the statistical power to detect a possible correlation between binding phenotypes and transcription patterns. On another hand, together with PfEMP1 or alone other parasite proteins expressed on the surface of IEs may take part in cytoadherence mechanism making difficult to reveal such correlation.

PfEMP-1 architecture is not randomly arranged since it has been observed that specific arrangement of CIDR and DBL domain tandems occurs more frequently to maintain a minimum structural function for PfEMP1 folding, export, and cytoadherence [52]. Therefore, the correlation among transcription patterns of group B variants, which are characterized by CIDR and DBL domains, binding phenotype to CD36, and severity of the disease reflects the existence of conserved phenotypes associated with cerebral malaria.

\section{Conclusion}

A higher number of $\mathrm{CM}$ isolates binds more to CD36, as compared to $\mathrm{UM}$ isolates, but there was no significant difference between $\mathrm{CM}$ and $\mathrm{UM}$ isolates in the binding levels to ICAM-1 and CSPG. CM isolates transcribed groups $\mathrm{A}, \mathrm{B}$, var2csa, var3, DC8, and $\mathrm{DC} 13$ at higher levels than UM isolates. These results support the role of these PfEMP-1 variants in CM. Likewise, the positive correlation between the high transcription level of group $B$ var genes and the increased binding of isolates from $\mathrm{CM}$ patients strengthens the implication of group B var encoding PfEMP-1 in the binding interaction with CD36 during cerebral malaria.

For its survival, the parasite has developed sophisticated mechanisms to bind to host receptors and establish acute or chronic infections. Hence, the identification of PfEMP-1 domains of group B var genes, probably CIDR1 domains, involved in CD36 binding during cerebral malaria could be targeted to prevent severe and complicated malaria.

\section{Abbreviations}

CD36: Cluster of differentiation; CM: Cerebral malaria; CSA: Chondroitin sulphate A; CSPG: Chondroitin sulfate proteoglycan; DC: Domain cassettes; HBMEC: Human brain microvascular endothelial cells; ICAM-1: Intercellular adhesion molecule 1; IEs: Plasmodium falciparum-infected erythrocytes; PfEMP-1: P. falciparum Erythrocyte Membrane Protein-1; UM: Uncomplicated malaria.

\section{Competing interests}

The authors declare that they have no competing interests.

\section{Authors' contributions}

RT, PD, NTN, and TA conceived the study design; TA SE, CA, and GS carried out sample collection, parasite cultures and cytoadhesion experiments; TA performed RNA extraction, qPCR experiments and results analysis and drafted the manuscript; MJA and AA carried out patient recruitment and treatment; RT, TA, NTN, and PD contributed in writing the manuscript. All authors have read, corrected and approved the final manuscript.

\section{Acknowledgements}

We would like to thank all children and their parents for participating in this study. We are grateful to the paediatricians and nurses in HOMEL, CNHU-HKM, and Suru-Léré for their participation in sample collection. We thank Prof Ayvivi and Dr Layla for facilitating our field work. UMR216 is part of the Laboratory of Excellence GR-Ex, reference ANR-11-LABX-0051, funded by the program

"Investissements d'avenir" of the French National Research Agency, reference ANR-11-IDEX-0005-02

Talleh Almelli was supported by Agence Inter-établissements de Recherche pour le Développement, and by fellowship grant from Foundation des Treilles. The funders had no role in study design, data collection and analysis, decision to publish or preparation of manuscript.

\section{Author details}

${ }^{1}$ Institut de Recherche pour le Développement (IRD), UMR 216 Mère et Enfant Face aux Infections Tropicales, 4, avenue de l'Observatoire, Paris 75270, France. ${ }^{2}$ PRES Sorbonne Paris Cité, Université Paris Descartes, Faculté de Pharmacie, Paris, France. ${ }^{3}$ Centre d'Etude et de recherche sur le Paludisme Associé à la Grossesse et l'Enfance (CERPAGE), Cotonou, Bénin. ${ }^{4}$ Département de pédiatrie, Hôpital Mère-enfant de la lagune (HOMEL), Cotonou, Bénin. ${ }^{5}$ Service de pédiatrie, Centre National Hospitalo-Universitaire (CNHU), Cotonou, Bénin. '5ervice de pédiatrie, Hôpital de zone de Suru-Léré, Cotonou, Bénin.

Received: 29 May 2014 Accepted: 29 July 2014

Published: 25 August 2014

\section{References}

1. Idro R, Marsh K, John CC, Newton CR: Cerebral malaria: mechanisms of brain injury and strategies for improved neurocognitive outcome. Pediatr Res 2010, 68:267-274.

2. MacPherson GG, Warrell MJ, White NJ, Looareesuwan S, Warrell DA: Human cerebral malaria. A quantitative ultrastructural analysis of parasitized erythrocyte sequestration. Am J Pathol 1985, 119:385-401. 
3. Pongponratn E, Riganti M, Punpoowong B, Aikawa M: Microvascular sequestration of parasitized erythrocytes in human falciparum malaria: a pathological study. Am J Trop Med Hyg 1991, 44:168-175.

4. van der Heyde HC, Nolan J, Combes V, Gramaglia I, Grau GE: A unified hypothesis for the genesis of cerebral malaria: sequestration, inflammation and hemostasis leading to microcirculatory dysfunction. Trends Parasitol 2006, 22:503-508.

5. Su XZ, Heatwole VM, Wertheimer SP, Guinet F, Herrfeldt JA, Peterson DS, Ravetch JA, Wellems TE: The large diverse gene family var encodes proteins involved in cytoadherence and antigenic variation of Plasmodium falciparum-infected erythrocytes. Cell 1995, 82:89-100.

6. Baruch DI, Pasloske BL, Singh HB, Bi X, Ma XC, Feldman M, Taraschi TF, Howard RJ: Cloning the $P$ Falciparum gene encoding PfEMP1, a malarial variant antigen and adherence receptor on the surface of parasitized human erythrocytes. Cell 1995, 82:77-87.

7. Jensen AT, Magistrado P, Sharp S, Joergensen L, Lavstsen T, Chiucchiuini A, Salanti A, Vestergaard LS, Lusingu JP, Hermsen R, Sauerwein R, Christensen J, Nielsen MA, Hviid L, Sutherland C, Staalsoe T, Theander TG: Plasmodium falciparum associated with severe childhood malaria preferentially expresses PfEMP1 encoded by group A var genes. J Exp Med 2004, 199:1179-1190.

8. Rottmann M, Lavstsen T, Mugasa JP, Kaestli M, Jensen AT, Muller D, Theander T, Beck HP: Differential expression of var gene groups is associated with morbidity caused by Plasmodium falciparum infection in Tanzanian children. Infect Immun 2006, 74:3904-3911.

9. Kyriacou HM, Stone GN, Challis RJ, Raza A, Lyke KE, Thera MA, Kone AK, Doumbo OK, Plowe CV, Rowe JA: Differential var gene transcription in Plasmodium falciparum isolates from patients with cerebral malaria compared to hyperparasitaemia. Mol Biochem Parasitol 2006, 150:211-218.

10. Lavstsen T, Turner L, Saguti F, Magistrado P, Rask TS, Jespersen JS, Wang CW, Berger SS, Baraka V, Marquard AM, Seguin-Orlando A, Willerslev E, Gilbert MT, Lusingu J, Theander TG: Plasmodium falciparum erythrocyte membrane protein 1 domain cassettes 8 and 13 are associated with severe malaria in children. Proc Natl Acad Sci U S A 2012, 109:E1791-E1800.

11. Bertin GI, Lavstsen T, Guillonneau F, Doritchamou J, Wang CW, Jespersen JS, Ezimegnon S, Fievet N, Alao MJ, Lalya F, Massougbodji A, Ndam NT, Theander TG, Deloron P: Expression of the domain cassette 8 Plasmodium falciparum erythrocyte membrane protein 1 is associated with cerebral malaria in Benin. PLoS One 2013, 8:e68368.

12. Claessens A, Adams Y, Ghumra A, Lindergard G, Buchan CC, Andisi C, Bull PC, Mok S, Gupta AP, Wang CW, Turner L, Arman M, Raza A, Bozdech Z, Rowe JA: A subset of group A-like var genes encodes the malaria parasite ligands for binding to human brain endothelial cells. Proc Natl Acad Sci U S A 2012, 109:E1772-E1781.

13. Avril M, Tripathi AK, Brazier AJ, Andisi C, Janes JH, Soma VL, Sullivan DJ Jr, Bull PC, Stins MF, Smith JD: A restricted subset of var genes mediates adherence of Plasmodium falciparum-infected erythrocytes to brain endothelial cells. Proc Natl Acad Sci U S A 2012, 109:E1782-E1790.

14. Chaiyaroj SC, Angkasekwinai P, Buranakiti A, Looareesuwan S, Rogerson SJ, Brown GV: Cytoadherence characteristics of Plasmodium falciparum isolates from Thailand: evidence for chondroitin sulfate a as a cytoadherence receptor. Am J Trop Med Hyg 1996, 55:76-80.

15. Salanti A, Dahlback M, Turner L, Nielsen MA, Barfod L, Magistrado P, Jensen AT, Lavstsen T, Ofori MF, Marsh K, Hviid L, Theander TG: Evidence for the involvement of VAR2CSA in pregnancy-associated malaria. J Exp Med 2004, 200:1197-1203.

16. Fried M, Duffy PE: Adherence of Plasmodium falciparum to chondroitin sulfate A in the human placenta. Science 1996, 272:1502-1504

17. Beeson JG, Brown GV, Molyneux ME, Mhango C, Dzinjalamala F, Rogerson SJ: Plasmodium falciparum isolates from infected pregnant women and children are associated with distinct adhesive and antigenic properties. J Infect Dis 1999, 180:464-472.

18. Ho M, Davis TM, Silamut K, Bunnag D, White NJ: Rosette formation of Plasmodium falciparum-infected erythrocytes from patients with acute malaria. Infect Immun 1991, 59:2135-2139.

19. Newbold C, Warn P, Black G, Berendt A, Craig A, Snow B, Msobo M, Peshu N, Marsh K: Receptor-specific adhesion and clinical disease in Plasmodium falciparum. Am J Trop Med Hyg 1997, 57:389-398.

20. Rogerson SJ, Tembenu R, Dobano C, Plitt S, Taylor TE, Molyneux ME: Cytoadherence characteristics of Plasmodium falciparum-infected erythrocytes from Malawian children with severe and uncomplicated malaria. Am J Trop Med Hyg 1999, 61:467-472.
21. Heddini A, Chen Q, Obiero J, Kai O, Fernandez V, Marsh K, Muller WA, Wahlgren M: Binding of Plasmodium falciparum-infected erythrocytes to soluble platelet endothelial cell adhesion molecule-1 (PECAM-1/CD31): frequent recognition by clinical isolates. Am J Trop Med Hyg 2001, 65:47-51.

22. Mayor A, Hafiz A, Bassat Q, Rovira-Vallbona E, Sanz S, Machevo S, Aguilar R, Cistero P, Sigauque B, Menendez C, Alonso PL, Chitnis CE: Association of severe malaria outcomes with platelet-mediated clumping and adhesion to a novel host receptor. PLoS One 2011, 6:e19422.

23. Ochola LB, Siddondo BR, Ocholla H, Nkya S, Kimani EN, Williams TN, Makale JO, Liljander A, Urban BC, Bull PC, Szestak T, Marsh K, Craig AG: Specific receptor usage in Plasmodium falciparum cytoadherence is associated with disease outcome. PLoS One 2011, 6:e14741.

24. Turner GD, Ly VC, Nguyen TH, Tran TH, Nguyen HP, Bethell D, Wyllie S, Louwrier K, Fox SB, Gatter KC, Day NP, White NJ, Berendt AR: Systemic endothelial activation occurs in both mild and severe malaria. Correlating dermal microvascular endothelial cell phenotype and soluble cell adhesion molecules with disease severity. Am J Pathol 1998, 152:1477-1487.

25. Heddini A, Pettersson F, Kai O, Shafi J, Obiero J, Chen Q, Barragan A, Wahlgren M, Marsh K: Fresh isolates from children with severe Plasmodium falciparum malaria bind to multiple receptors. Infect Immun 2001, 69:5849-5856.

26. Akogbeto M: [Entomological study on the malaria transmission in coastal and lagoon areas: the case of a village built on a brackish lake] (in French). Ann Soc Belg Med Trop 1995, 75:219-227.

27. World Health Organization: Severe falciparum malaria. Trans $R$ Soc Trop Med Hyg 2000, 94(suppl 1):1-90.

28. Bigey P, Gnidehou S, Doritchamou J, Quiviger M, Viwami F, Couturier A, Salanti A, Nielsen MA, Scherman D, Deloron P, Tuikue Ndam N: The NTS-DBL2X region ofVAR2CSA induces cross-reactive antibodies that inhibit adhesion of several Plasmodium falciparum isolates to chondroitin sulfate A. J Infect Dis 2011, 204:1125-1133.

29. Salanti A, Staalsoe T, Lavstsen T, Jensen AT, Sowa MP, Arnot DE, Hviid L, Theander TG: Selective upregulation of a single distinctly structured var gene in chondroitin sulphate A-adhering Plasmodium falciparum involved in pregnancy-associated malaria. Mol Microbiol 2003, 49:179-191.

30. Tuikue Ndam NG, Salanti A, Bertin G, Dahlback M, Fievet N, Turner L, Gaye A, Theander T, Deloron P: High level of var2csa transcription by Plasmodium falciparum isolated from the placenta. J Infect Dis 2005, 192:331-335.

31. Francis SE, Malkov VA, Oleinikov AV, Rossnagle E, Wendler JP, Mutabingwa TK, Fried M, Duffy PE: Six genes are preferentially transcribed by the circulating and sequestered forms of Plasmodium falciparum parasites that infect pregnant women. Infect Immun 2007, 75:4838-4850

32. Plowe CV, Djimde A, Bouare M, Doumbo O, Wellems TE: Pyrimethamine and proguanil resistance-conferring mutations in Plasmodium falciparum dihydrofolate reductase: polymerase chain reaction methods for surveillance in Africa. Am J Trop Med Hyg 1995, 52:565-568.

33. Snounou G, Zhu X, Siripoon N, Jarra W, Thaithong S, Brown KN, Viriyakosol S: Biased distribution of msp1 and msp2 allelic variants in Plasmodium falciparum populations in Thailand. Trans R Soc Trop Med Hyg 1999, 93:369-374.

34. Raventos-Suarez C, Kaul DK, Macaluso F, Nagel RL: Membrane knobs are required for the microcirculatory obstruction induced by Plasmodium falciparum-infected erythrocytes. Proc Natl Acad Sci U S A 1985, 82:3829-3833.

35. Baruch DI, Gormely JA, Ma C, Howard RJ, Pasloske BL: Plasmodium falciparum erythrocyte membrane protein 1 is a parasitized erythrocyte receptor for adherence to $\mathrm{CD} 36$, thrombospondin, and intercellular adhesion molecule 1. Proc Natl Acad Sci U S A 1996, 93:3497-3502.

36. Udomsangpetch R, Taylor BJ, Looareesuwan S, White NJ, Elliott JF, Ho M: Receptor specificity of clinical Plasmodium falciparum isolates: nonadherence to cell-bound E-selectin and vascular cell adhesion molecule-1. Blood 1996, 88:2754-2760.

37. Cooke BM, Berendt AR, Craig AG, MacGregor J, Newbold CI, Nash GB: Rolling and stationary cytoadhesion of red blood cells parasitized by Plasmodium falciparum: separate roles for ICAM-1, CD36 and thrombospondin. Br J Haematol 1994, 87:162-170.

38. Turner GD, Morrison H, Jones M, Davis TM, Looareesuwan S, Buley ID, Gatter KC, Newbold Cl, Pukritayakamee S, Nagachinta B, White NJ, Berendt AR: An immunohistochemical study of the pathology of fatal malaria. Evidence 
for widespread endothelial activation and a potential role for intercellular adhesion molecule- 1 in cerebral sequestration. Am J Pathol 1994, 145:1057-1069.

39. Wassmer SC, Coltel N, Combes V, Grau GE: Pathogenesis of cerebral malaria: facts and hypotheses. Med Trop (Mars) 2003, 63:254-257.

40. Wassmer SC, Lepolard C, Traore B, Pouvelle B, Gysin J, Grau GE: Platelets reorient Plasmodium falciparum-infected erythrocyte cytoadhesion to activated endothelial cells. J Infect Dis 2004, 189:180-189.

41. Chen Q, Heddini A, Barragan A, Fernandez V, Pearce SF, Wahlgren M: The semiconserved head structure of Plasmodium falciparum erythrocyte membrane protein 1 mediates binding to multiple independent host receptors. J Exp Med 2000, 192:1-10.

42. Oleinikov AV, Amos E, Frye IT, Rossnagle E, Mutabingwa TK, Fried M, Duffy PE: High throughput functional assays of the variant antigen PfEMP1 reveal a single domain in the 3D7 Plasmodium falciparum genome that binds ICAM1 with high affinity and is targeted by naturally acquired neutralizing antibodies. PLoS Pathog 2009, 5:e1000386.

43. Bengtsson A, Joergensen L, Barbati ZR, Craig A, Hviid L, Jensen AT: Transfected HEK293 cells expressing functional recombinant intercellular adhesion molecule 1 (ICAM-1)-a receptor associated with severe Plasmodium falciparum malaria. PLoS One 2013, 8:e69999.

44. Bengtsson A, Joergensen L, Rask TS, Olsen RW, Andersen MA, Turner L, Theander TG, Hviid L, Higgins MK, Craig A, Brown A, Jensen AT: A novel domain cassette identifies Plasmodium falciparum PfEMP1 proteins binding ICAM-1 and is a target of cross-reactive, adhesion-inhibitory antibodies. J Immunol 2013, 190:240-249.

45. Vigan-Womas I, Guillotte M, Juillerat A, Hessel A, Raynal B, England P, Cohen $\mathrm{JH}$, Bertrand O, Peyrard T, Bentley GA, Lewit-Bentley A, Mercereau-Puijalon $\mathrm{O}$ : Structural basis for the $\mathrm{ABO}$ blood-group dependence of Plasmodium falciparum rosetting. PLoS Pathog 2012, 8:e1002781.

46. Avril M, Brazier AJ, Melcher M, Sampath S, Smith JD: DC8 and DC13 var genes associated with severe malaria bind avidly to diverse endothelial cells. PLoS Pathog 2013, 9:e1003430

47. Doritchamou J, Bertin G, Moussiliou A, Bigey P, Viwami F, Ezinmegnon S, Fievet N, Massougbodji A, Deloron P, Tuikue Ndam N: First-trimester Plasmodium falciparum infections display a typical "placental" phenotype. J Infect Dis 2012, 206:1911-1919.

48. Smith JD, Kyes S, Craig AG, Fagan T, Hudson-Taylor D, Miller LH, Baruch DI, Newbold Cl: Analysis of adhesive domains from the A4VAR Plasmodium falciparum erythrocyte membrane protein-1 identifies a CD36 binding domain. Mol Biochem Parasitol 1998, 97:133-148.

49. Robinson BA, Welch TL, Smith JD: Widespread functional specialization of Plasmodium falciparum erythrocyte membrane protein 1 family members to bind CD36 analysed across a parasite genome. Mol Microbiol 2003, 47:1265-1278.

50. Gamain B, Smith JD, Miller LH, Baruch DI: Modifications in the CD36 binding domain of the Plasmodium falciparum variant antigen are responsible for the inability of chondroitin sulfate $A$ adherent parasites to bind CD36. Blood 2001, 97:3268-3274.

51. Turner L, Lavstsen T, Berger SS, Wang CW, Petersen JE, Avril M, Brazier AJ, Freeth J, Jespersen JS, Nielsen MA, Magistrado P, Lusingu J, Smith JD, Higgins MK, Theander TG: Severe malaria is associated with parasite binding to endothelial protein C receptor. Nature 2013, 498:502-505.

52. Rask TS, Hansen DA, Theander TG, Gorm Pedersen A, Lavstsen T: Plasmodium falciparum erythrocyte membrane protein 1 diversity in seven genomes-divide and conquer. PLoS Comput Biol 2010, 6:e1000933.

doi:10.1186/1475-2875-13-333

Cite this article as: Almelli et al:: Cytoadherence phenotype of

Plasmodium falciparum-infected erythrocytes is associated with specific pfemp-1 expression in parasites from children with cerebral malaria.

Malaria Journal 2014 13:333.

\section{Submit your next manuscript to BioMed Central and take full advantage of:}

- Convenient online submission

- Thorough peer review

- No space constraints or color figure charges

- Immediate publication on acceptance

- Inclusion in PubMed, CAS, Scopus and Google Scholar

- Research which is freely available for redistribution

Submit your manuscript at www.biomedcentral.com/submit
C Biomed Central 